\title{
Anti-plasmodial activity of Ailanthus excelsa
}

\author{
Mario Dell'Agli ${ }^{\text {a,* }}$, Germana V. Galli ${ }^{\text {a }}$, Silvia Parapini ${ }^{\mathrm{b}}$, Nicoletta Basilico ${ }^{\mathrm{b}}$, \\ Donatella Taramelli ${ }^{b}$, Ataa Said ${ }^{\mathrm{c}}$, Khaled Rashed $^{\mathrm{c}}$, Enrica Bosisio ${ }^{\mathrm{a}}$ \\ a Department of Pharmacological Sciences, University of Milan, Milan, Italy \\ ${ }^{\mathrm{b}}$ Department of Public Health, Microbiology and Virology, University of Milan, Milan, Italy \\ ${ }^{\mathrm{c}}$ National Research Centre, Pharmacognosy Department, Dokki, Giza, Egypt
}

Received 25 January 2007; accepted 5 November 2007

Available online 31 December 2007

\begin{abstract}
The anti-plasmodial activity of Ailanthus excelsa stem bark was investigated. The methanolic extract inhibited in vitro growth of chloroquine-sensitive (D10) and resistant strains (W2) of Plasmodium falciparum ( $\mathrm{IC}_{50} 4.6$ and $2.8 \mu \mathrm{g} / \mathrm{ml}$, respectively). The effect was retained in the chloroform fraction ( 3.1 and $2.1 \mu \mathrm{g} / \mathrm{ml}$, respectively). The anti-plasmodial activity could be ascribed to the impairment of haemoglobin degradation through the inhibition of plasmepsin II activity $\left(\mathrm{IC}_{50}\right.$ of $\left.13.43 \pm 1.74 \mu \mathrm{g} / \mathrm{ml}\right)$ and of the haem detoxification to haemozoin.
\end{abstract}

(C) 2007 Elsevier B.V. All rights reserved.

Keywords: Ailanthus excelsa; Malaria; Anti-plasmodial activity; Plasmepsins; Haemozoin

\section{Introduction}

Ailanthus excelsa is a fast-growing and large tree, up to $25 \mathrm{~m}$ tall, commonly known as Indian Tree of Heaven. In traditional medicine the bark is being used as anti-spasmodic and expectorant [1]. A. excelsa has been shown to possess anti-bacterial [2], anti-leukemic [3] and anti-fungal activities [4]. As for the other Ailanthus species $A$. excelsa contains the bitter principles known as quassinoids. Quassinoids isolated from Ailanthus spp. possess several biological activities including anti-tumor [5], anti-viral [6,7], anti-tuberculosis [8] properties reported in a Review [9]. Quassinoids were also shown to be the active principles responsible for the anti-malarial activity of Ailanthus altissima. The chloroform extract obtained from the stem and root bark of this plant inhibited in vitro the growth of Plasmodium falciparum and was active against $P$. berghei infections in mice [10]. The anti-plasmodial activity has been mainly referred to the presence of ailanthone, a quassinoid responsible for the anti-malarial activity recently observed also for the seedlings of A. altissima [11].

\footnotetext{
is Mario Dell'Agli and Germana V. Galli contributed equally to this paper

* Corresponding author. Tel.: +44 025031 8345; fax: +44 0250318391.

E-mail address: mario.dellagli@unimi.it (M. Dell’Agli). 
Malaria represents one of the key priorities for the WHO due to the unavailability of a vaccine and the spread and intensification of drug resistance over the last 15-20 years.

Modern pharmaceuticals are unavailable and/or unaffordable for the populations living in those areas affected by malaria. In such conditions non-industrialized countries rely on traditional medicine and locally grown plants for the cure of malaria. Research Initiative on Traditional Antimalarial Methods (RITAM) is promoting the use of traditional remedies based on the concept of evidence-based medicine. While A. altissima and other plants of the Simaroubaceae have been investigated for their efficacy as anti-malarials [12], A. excelsa, which is used as anti-pyretic [1], was never explored at this regard. The present work was undertaken to evaluate in vitro the anti-plasmodial activity of extracts from $A$. excelsa and to investigate the mechanism of action. At this aim the extracts were assayed on chloroquinesensitive and resistant strains of $P$. falciparum at the intra-erythrocytic stage. The survival of malaria parasites in the host cells relies on the degradation of haemoglobin in the food vacuole with the involvement of several proteinases, including plasmepsins (PLM), a family of aspartyl proteinases specific to P.f. The inhibition of PLM leads to the starvation of the parasite [13], then it represents a feasible mechanism of action for the anti-plasmodial effect. In addition, once haemoglobin is degraded, the parasite detoxifies the excess of released haem by converting it into the crystalline pigment haemozoin [14]. A synthetic compound, called $\beta$-haematin spectroscopically identical to the native pigment can be obtained in vitro. Quinoline anti-malarials have been shown to inhibit $\beta$-haematin formation [15]. Then we evaluated the ability of $A$. excelsa to inhibit PLM II and IV and the formation of $\beta$-haematin in vitro.

\section{Experimental}

\subsection{Plant material}

A. excelsa Roxb (Simaroubaceae), stem bark collected from Zoo garden, Giza, Egypt, in April 2002,was identified by Prof. Dr. Kamal El Batanony, Professor of Taxonomy and Botany, Faculty of Science, Cairo University. A voucher was deposited in National Research Centre Herbarium.

\subsection{Extraction}

Dried powdered stem bark $(1 \mathrm{~kg})$ was Soxhlet-extracted with petroleum ether, $\mathrm{Et}_{2} \mathrm{O}, \mathrm{CHCl}_{3}$, and $\mathrm{MeOH}(70 \%)$ and concentrated in vacuo. $\mathrm{MeOH}$ extract $(67.5 \mathrm{~g})$ was added with $500 \mathrm{ml}$ of distilled water and extracted with $\mathrm{CHCl}_{3}$. The $\mathrm{CHCl}_{3}$ solution was shaken with $10 \% \mathrm{HCl}$. The acid layer was made alkaline with $\mathrm{NH}_{4} \mathrm{OH}$ to $\mathrm{pH} 9$, then it was extracted with $\mathrm{CHCl}_{3}$. The $\mathrm{CHCl}_{3}$ layer dried was evaporated giving $1.7 \mathrm{~g}$ of crude alkaloid chromatographed over silica gel column using $\mathrm{CHCl}_{3}$ and increasing polarity with $\mathrm{MeOH}$. Elution with chloroform gave canthin-6-one identified by comparison with the reported spectral data $[16,17]$.

\subsection{Drug susceptibility assay on P. falciparum}

The CQ-sensitive (D10) and the CQ-resistant (W2) strains of P. falciparum were sustained in vitro as described by Trager and Jensen [18]. Parasites were maintained at 5\% hematocrit (human type A-positive red blood cells) in RPMI 1640 (Gibco BRL, $\mathrm{NaHCO}_{3} 24 \mathrm{mM}$ ) medium with the addition of $10 \%$ heat-inactivated A-positive human plasma, $20 \mathrm{mM}$ Hepes (Euroclone), $2 \mathrm{mM}$ glutamine (Euroclone). Compounds were dissolved in either water (chloroquine) or DMSO and then diluted with the medium to achieve the required concentrations (final DMSO concentration $<1 \%$ ). Asynchronous cultures with parasitemia of $1-1.5 \%$ and $1 \%$ final hematocrit were aliquoted into the plates and incubated for $72 \mathrm{~h}$ at $37^{\circ} \mathrm{C}$. Parasite growth was determined spectrophotometrically $\left(\mathrm{OD}_{650}\right)$ by measuring the activity of the parasite lactate dehydrogenase (LDH), according to a modified version of Makler's method in control and drugtreated cultures [19]. Anti-plasmodial activity is expressed as the $50 \%$ inhibitory concentrations $\left(\mathrm{IC}_{50}\right)$, each $\mathrm{IC}_{50}$ value is the mean $\pm \mathrm{SD}$ of at least three separate experiments performed in duplicate.

\subsection{PLMs inhibition assays}

Recombinant pro-PLM II and IV were purified from BL21-(DE3) pLysS E. coli (Invitrogen, Milano) according to Hill J. et al. [20], with slight modifications [21]. Protein concentration was determined according to the method of 

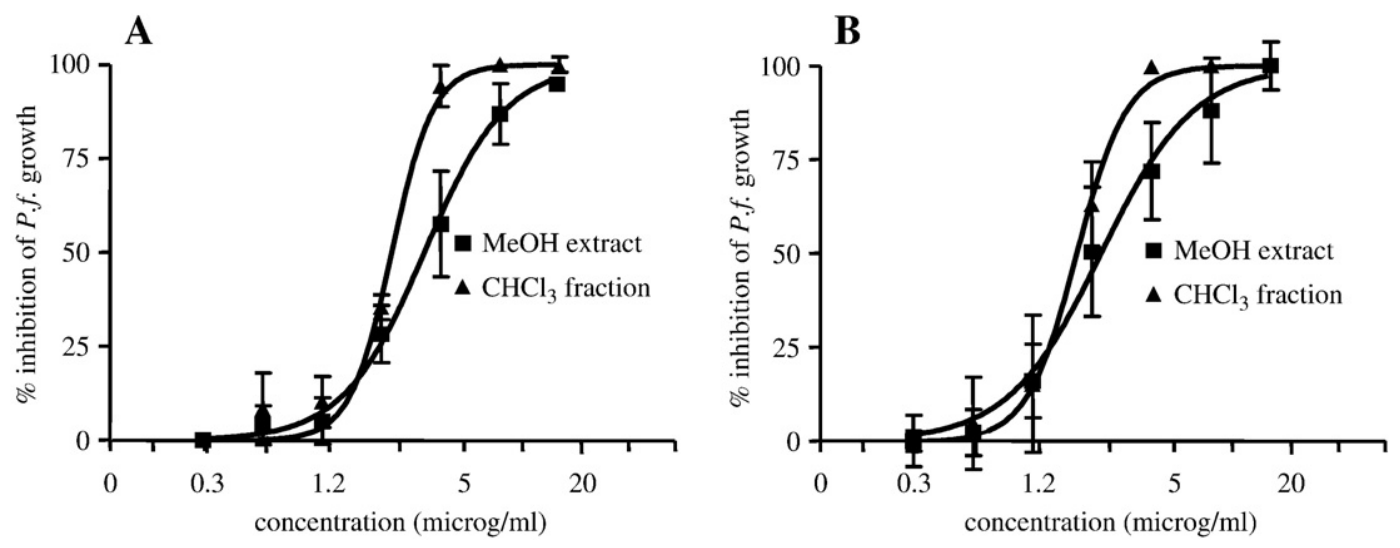

Fig. 1. Anti-plasmodial activity of $\mathrm{MeOH}$ and $\mathrm{CHCl}_{3}$ extracts against $P$. falciparum $\mathrm{D} 10$ (A) and W2 (B) strains.

Bradford [22]. Proteins were diluted to the final concentration of $0.5 \mathrm{mg} / \mathrm{ml}$ in $50 \%$ glycerol and stored at $-20{ }^{\circ} \mathrm{C}$. ProPLM II and IV were activated by addition of one tenth volume of $100 \mathrm{mM}$ sodium acetate buffer $\mathrm{pH} 4.7$ by incubation at $37^{\circ} \mathrm{C}$ for $90 \mathrm{~min}$. The enzyme activity of PLM II and IV was evaluated spectrophotometrically at $300 \mathrm{~nm}$ as described [20].

The $\mathrm{CHCl}_{3}$ fraction from A. excelsa dissolved in DMSO was tested at 5-50 $\mu \mathrm{g} / \mathrm{ml}$ (final solvent concentration $1 \%$ of the sample volume). PS777621 [23] was used as the reference compound. The assays were conducted twice in triplicate. Inhibition curves and $\mathrm{IC}_{50}$ values were calculated by a non-linear regression for sigmoidal curves using Graph Pad Prism 4.

\section{5. $\beta$-Haematin inhibitory assay}

$\beta$-Haematin formation was assayed by a spectrophotometric microassay BHIA ( $\beta$-Haematin inhibitory assay) previously reported [24]. Haemin dissolved in DMSO $(0.4 \mu \mathrm{mol} /$ well $)$ was distributed in 96-well microplates. $\mathrm{CHCl}_{3}$ fraction dissolved in DMSO was added in doses ranging from 0.3 to $5 \mathrm{mg} / \mathrm{ml}$. Chloroquine was used as reference compound and showed an $\mathrm{IC}_{50}$ of $0.9 \pm 0.05 \mathrm{mg} / \mathrm{ml}($ mean $\pm \mathrm{SD}$ ).

\subsection{Cytotoxicity assay}

Cytotoxicity was evaluated in human fibroblasts from skin biopsies. Fibroblasts $\left(8 \times 10^{4} /\right.$ well $)$ were grown in 24 well plates with DMEM (Dulbecco's modified Eagle's medium) containing 10\% fetal calf serum, 1\% penicillin/ streptomycin, and 1\% L-glutamine as previously described [25]. Cell proliferation was followed by the MTT (3-[4,5-

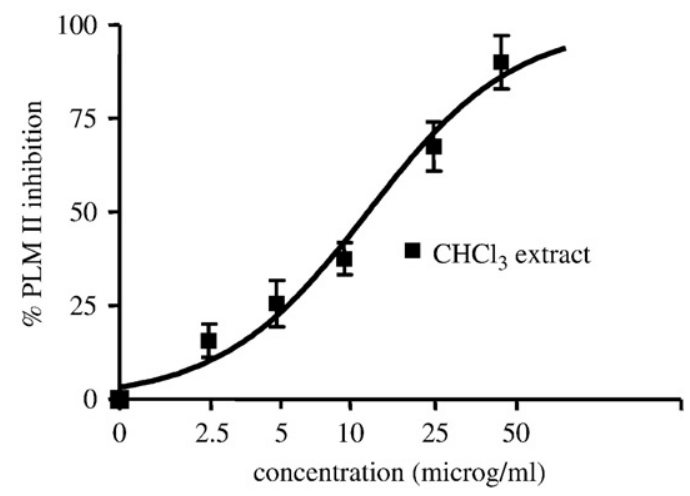

Fig. 2. Effect of the $\mathrm{CHCl}_{3}$ fraction on PLM II. $\mathrm{IC}_{50}$ value, expressed as the mean $\pm \mathrm{SD}$ of two experiments in triplicate, was $13.4 \pm 1.7 \mu \mathrm{g} / \mathrm{ml}$. 
Table 1

Cytotoxicity vs anti-plasmodial activity of the $A$. excelsa stem bark methanolic extract and $\mathrm{CHCl}_{3}$ fraction

\begin{tabular}{llll}
\hline Material & $\mathrm{HF}$ & $\frac{\mathrm{D} 10}{2}$ & $\mathrm{~W} 2$ \\
\cline { 2 - 4 } & $\mathrm{LC}_{50} \pm \mathrm{SD}(\mu \mathrm{g} / \mathrm{ml})$ & $\mathrm{IC}_{50} \pm \mathrm{SD}(\mu \mathrm{g} / \mathrm{ml})$ & $2.8 \pm 0.88$ \\
\hline $\mathrm{MeOH}$ extract & $116 \pm 19$ & $4.6 \pm 1.4$ & $2.1 \pm 0.58$ \\
$\mathrm{CHCl}_{3}$ fraction & $46 \pm 7.5$ & $3.1 \pm 0.15$ & $\mathrm{IC}(\mu \mathrm{g} / \mathrm{ml})$ \\
\hline
\end{tabular}

dimethylthiazol-2-yl]-2,5-diphenyltetrazolium bromide) test [26], in the presence of the $\mathrm{MeOH}$ extract and $\mathrm{CHCl}_{3}$ fraction $(0-100 \mu \mathrm{g} / \mathrm{ml})$ and $\mathrm{LC}_{50}$ were calculated.

\section{Results}

The $\mathrm{MeOH}$ extract from the stem bark of $A$. excelsa inhibited parasite growth in a dose dependent manner, with $\mathrm{ICs}_{50}$ of 4.6 and $2.8 \mu \mathrm{g} / \mathrm{ml}$ on chloroquine-sensitive and -resistant strains, respectively (Fig. 1). After fractionation, the anti-plasmodial activity was retained by the $\mathrm{CHCl}_{3}$ fraction ( $\mathrm{IC}_{50}$ of 3.1 and $2.1 \mu \mathrm{g} / \mathrm{ml}$ on D10 and W2, respectively). To investigate the mechanism of action, we evaluated whether the $\mathrm{CHCl}_{3}$ fraction inhibited recombinant PLM II (Fig. 2), PLM IV, and the formation of $\beta$-haematin. $\mathrm{CHCl}_{3}$ fraction reduced PLM II activity in a concentration dependent manner $\left(\mathrm{IC}_{50}\right.$ of $13.4 \pm 1.7 \mu \mathrm{g} / \mathrm{ml}$, mean $\pm \mathrm{SD}$ ), while was inactive against PLM IV. The $\mathrm{CHCl}_{3}$ fraction inhibited also $\beta$-hematin formation dose dependently. At the highest dose tested $(5 \mathrm{mg} / \mathrm{ml})$ the inhibition was $37.7 \%$.

As shown in Table 1, the $\mathrm{MeOH}$ extract and the $\mathrm{CHCl}_{3}$ fraction were not devoid of cytotoxicity, but the $\mathrm{MeOH}$ extract was less cytotoxic than the $\mathrm{CHCl}_{3}$ fraction $\left(\mathrm{LC}_{50}\right.$ of $\left.116 \mu \mathrm{g} / \mathrm{ml} \mathrm{vs} 45.5 \mu \mathrm{g} / \mathrm{ml}\right)$.

\section{Discussion}

In the present study it is reported that $A$. excelsa stem bark methanol extract is active in vitro against both chloroquine-sensitive and -resistant strains of $P$. falciparum, similar to A. altissima stem bark [10]. Our results suggest that extracts from $A$. excelsa stem bark exert anti-plasmodial activity through the inhibition of PLM II and by halting the haem detoxification process. Surprisingly, A. excelsa $\mathrm{CHCl}_{3}$ extract was selective against PLM II, being inactive on PLM IV.

A. excelsa contains quassinoids [27], and $\beta$-carboline alkaloids, including canthin-6-one [28]. Canthin-6-one exhibited anti-plasmodial activity against W2 P.f. clone with $\mathrm{IC}_{50}$ of $2.2 \mu \mathrm{g} / \mathrm{ml}$, a value very close to that of the $\mathrm{CHCl}_{3}$ fraction, as reported in the present work (Table 1). In a previous study, quassinoids were shown to exhibit anti-malarial effect through the inhibition of protein synthesis [9]. It cannot be excluded however that quassinoids and canthin-6-one and/or other $\beta$-carboline alkaloids act also against other targets such as the breakdown of haemoglobin and the haem detoxification to haemozoin. Either, other constituents of $A$. excelsa stem bark may act as the active principles.

Although the cytotoxicity studies revealed an anti-proliferative effect on mammalian cells by the $\mathrm{MeOH}$ extract, the $\mathrm{LC}_{50}$ on human fibroblasts was 25 and 42 times higher than the $\mathrm{IC}_{50}$ against $P$. falciparum $\mathrm{D} 10$ and $\mathrm{W} 2$ strains, respectively. Cytotoxicity increased when the crude $\mathrm{MeOH}$ extract was fractionated to give the $\mathrm{CHCl}_{3}$ fraction, likely for the presence of higher concentrations of alkaloids which were found cytotoxic against tumor cell lines [29,30]. In conclusion A. excelsa, as other species of Ailanthus, possesses anti-plasmodial activity. The effect might be ascribable to the inhibition of haemoglobin cleavage and/or haem detoxification.

\section{Acknowledgements}

This work was funded by FIRST 2005 from the University of Milan.

\section{References}

[1] Anis M, Sharma MP, Iqbal M. Pharmacol Biol 2000;38:241.

[2] Shrimali M, Jain DC, Darokar MP, Sharma RP. Phytother Res 2001;15:165.

[3] Ogura M, Cordell GA, Kinghorn AD, Farnsworth NR. Lloydia 1977;40:579. 
[4] Joshi BC, Pandey A, Chaurasia L, Pal M, Sharma RP, Khare A. Fitoterapia 2003;74:689.

[5] Murakami C, Fukamiya N, Tamura S, Okano M, Bastow KF, Tokuda H, et al. Bioorganic Med Chem 2004;12:4963.

[6] Rahman S, Fukamiya N, Ohno N, Tokuda H, Nishino H, Tagahara K, et al. Chem Pharm Bull 1997;45:675.

[7] Kubota K, Fukamiya N, Tokuda H, Nishino H, Tagahara K, Lee KH, et al. Cancer Lett 1997;113:165.

[8] Rahman S, Fukamiya N, Okano M, Tagahara K, Lee KH. Chem Pharm Bull 1997;45:1527.

[9] Guo Z, Vangapandu S, Sindelar RW, Walker LA, Sindelar RD. Curr Med Chem 2005;12:173.

[10] Bray DH, Boardman P, O’Neill MJ, Chan TH, Phillipson JD. Phytother Res 1987;1:22.

[11] Okunade AL, Bikoff RE, Casper SJ, Oksman A, Goldberg DE, Lewis WH. Phytother Res 2003;17:675.

[12] Wright CW. J Ethnopharmacol 2005;100:67.

[13] Ersmark K, Samuelsson B, Hallberg A. Med Res Rev 2006;26:626.

[14] Olliaro PL, Yuthavong Y. Pharmacol Ther 1999;81:91.

[15] Egan TJ, Marques HM. Coord Chem Rev 1999;190-192:493.

[16] Ohmoto T, Tanaka R, Nikaido T. Chem Pharm Bull 1976;24:1532.

[17] Mitsunaga K, Koike K, Tanaka T, Ohkawa Y, Kobayashi Y, Sawaguchi T, et al. Phytochemistry 1994;35:799.

[18] Trager W, Jensen JB. Science 1976;193:673.

[19] Makler MT, Ries JM, Williams JA, Bancroft JE, Piper RC, Gibbins BL, et al. Am J Trop Med Hyg 1993;48:739.

[20] Hill J, Tyas L, Phylip LH, Kay J, Dunn BM, Berry C. FEBS Lett 1994;352:155.

[21] Dell'Agli M, Parapini S, Galli G, Vaiana N, Taramelli D, Sparatore A, et al. J Med Chem 2006;49:7440.

[22] Bradford MM. Anal Biochem 1976;72:248.

[23] Carroll CD, Patel H, Johnson TO, Guo T, Orlowski M, He ZM, et al. Bioorg Med Chem Lett 1998;8:2315.

[24] Parapini S, Basilico N, Pasini E, Egan TJ, Olliaro P, Taramelli D. Exp Parasitol 2000;96:249.

[25] Verotta L, Dell'Agli M, Giolito A, Guerrini M, Cabalion P, Bosisio E. J Nat Prod 2001;64:603.

[26] Denizot F, Lang R. J Immunol Methods 1986;89:271.

[27] Joshi BC, Pandey A, Sharma RP, Khare A. Phytochemistry 2003;62:579.

[28] Cordell GA, Ogura M, Farnsworth NR. Lloydia 1978;41:166.

[29] Kuo PC, Shi LS, Damu AG, Su CR, Huang CH, Ke CH. J Nat Prod 2003;66:1324.

[30] De Feo V, Martino LD, Santoro A, Leone A, Pizza C, Franceschelli S, et al. Phytother Res 2005;19:226. 